
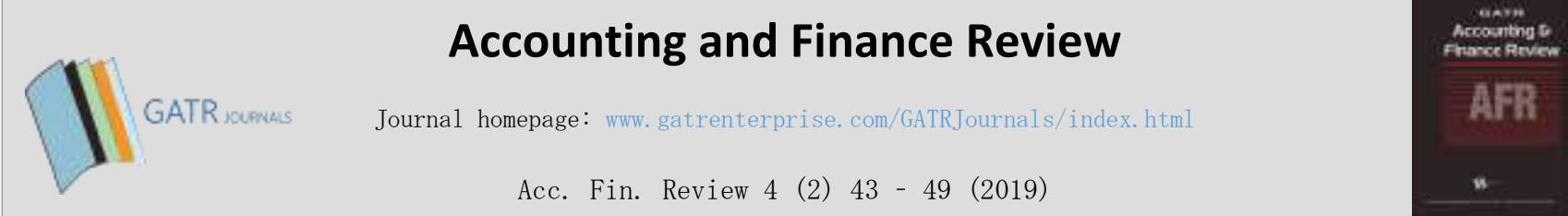

\title{
Company Characteristics, Corporate Governance, Audit Quality Impact on Earnings Management
}

\author{
Friska Firnanti ${ }^{1 *}$, Kashan Pirzada ${ }^{2}$, Budiman $^{3}$ \\ ${ }^{1,3}$ Trisakti School of Management, Kyai Tapa No. 20, 11440, Jakarta, Indonesia \\ ${ }^{2}$ Tunku Puteri Intan Safinaz School of Accountancy, Universiti Utara Malaysia, Kedah, Malaysia
}

\begin{abstract}
Objective - The purpose of this research is to empirically examine how company characteristics, corporate governance and audit quality affect earnings management.

Methodology/Technique - The population used for this research is manufacturing companies listed on the Indonesian Stock Exchange between 2013 and 2015. The sampling method used in this research is purposive sampling. 64 companies are examined, with 192 items of data being obtained.

Findings - This research also uses statistical testing through a multiple regression. The results show that return on assets, financial leverage, free cash flow, and sales growth all have an influence on earnings management. Meanwhile, other variables such as managerial ownership, institutional ownership, board size, the presence of an audit committee, firm size, and audit quality have no significant effect on earnings management.

Novelty - In this research, company characteristics are proxied with the return on assets, financial leverage, firm size, free cash flow, and sales growth, while corporate governance is proxied with managerial ownership, institutional ownership, board size, and the presence of an audit committee.
\end{abstract}

Type of Paper: Empirical.

Keywords: Company Characteristics; Corporate Governance; Audit Quality; Earnings Management; Agency Theory.

Reference to this paper should be made as follows: Firnanti, F.; Pirzada, K.; Budiman. (2019). Company Characteristics, Corporate Governance, Audit Quality Impact on Earnings Management, Acc. Fin. Review, 4 (2): 43 49 https://doi.org/10.35609/afr.2019.4.2(2)

JEL Classification: M40, M41, M49.

\section{Introduction}

Financial statements are an important source of information for many stakeholders. However, companies often use various earnings management techniques to improve the appearance of their financial statements. Earnings management occurs largely due to the inconsistency between the interests of shareholders and management, which can be described by the agency theory.

\footnotetext{
* Paper info: Revised: March 13, 2019

Accepted: July 12, 2019

* Corresponding author: Friska Firnanti

E-mail: friska@stietrisakti.ac.id

Affiliation: Accounting, Trisakti School of Management, Indonesia
} 
Agustia (2013) states that earnings management reflects the decision of a company manager to use certain accounting policies that enable the company to achieve its desired goals. One such example of this is the increasing of profits or reduction in the reported levels of loss. An important function of corporate governance is to ensure the quality of the financial reporting process (Aygun, 2010). Abdel-Azim and Ibrahim (2014) states that the complex and vulnerable accrual basis of these interests leads to manipulation of, and irregularities within, a company's financial statements.

Company characteristics, such as return on assets, financial leverage, firm size, free cash flow, and sales growth, are important factors affecting the actions of a company's management. Corporate governance therefore acts as a mechanism of control between these competing interests. Corporate governance through managerial ownership, institutional ownership, board size, and the use of an audit committee, aims to minimize the occurrence of earnings management practices. In addition, the execution of a high quality audit is also expected to minimize earnings management activities. The integrity of financial statements is said to be improved where a qualified and independent auditor has conducted an audit. Companies therefore rely on the services of qualified and professional auditors to reduce the opportunity for management to take adverse actions to maximize their personal profit (Zeptian and Rohman, 2013).

This paper aims to explore the relationship between audit quality and the discretionary accruals carried out by social leaders in an Indonesia context. Secondly, the study will examine the effect of other factors linked primarily with corporate governance (such as the board of directors, ownership structure and institutional investment) and agency costs (the level of indebtedness, the size of the firm and the way leaders are remunerated) on earnings management. The study ultimately advocates for the development of an explanatory model of earnings management in accordance with audit quality, the characteristics of the firm and its governance environment.

This paper is organized as follows: the second section provides an overview of the literature concerning earnings management and audit quality, agency costs and the mechanisms of corporate governance. Following this, the sample and the methodology used will be presented. The next section will discuss the results of the study and the final section of this paper will provide concluding remarks.

\section{Literature Review}

The present research pursues three main objectives: to identify the nature of the relationship between earnings management and audit quality; the affect of company characteristics on earning management; and the impact of corporate governance characteristics on earning management, from the perspective of the agency theory.

\subsection{Agency Theory}

The agency relationship is depicted as a contractual relationship in which the principal appoints another person, known as the agent, to perform services on their behalf, including to make decisions for them (Jensen and Meckling, 1976). The contract between the principal and the agent necessarily creates a separation between the shareholder as the principal, and the management as the agent, which may give rise to a conflict of interest if an agent fails to act in accordance with the principal's wishes (Wiyadi et. al, 2015). In the corporate context, this conflict may result in the agent preparing financial statements in a way that benefits their interests only. Therefore, in order to gain some benefit, the agent may produce financial statements that are inconsistent with reality.

\subsection{Return on Asset and Earnings Management}

Return on assets refers to a company's ability to earn an overall profit by operating its assets (Yuliana and Trisnawati, 2015). A decrease in earnings may reduce the appeal of the company to investors. Companies 
that produce substantial earnings will be more motivated to perform earnings-driven income in order to maintain their profit levels, or even increase their profit from year to year (Wiyadi et al., 2015). Based on this explanation, the following hypothesis will be tested:

H1: Return on assets has an effect on earnings management.

\subsection{Financial Leverage and Earnings Management}

Leverage indicates the amount of assets a company owns that are financed by debt. A high level of leverage indicates a higher risk for investors (Guna and Herawaty, 2010). The higher the risk of the company, the more likely management will engage in earnings management activities (Savitri, 2014). Based on this explanation, the following hypothesis will be tested:

H2: Financial leverage has an effect on earnings management.

\subsection{Firm Size and Earnings Management}

Large companies are more likely to be noticed by the general public when compared to smaller firms, as the decisions of large companies tend to have far more impact on the public at large. Therefore, large companies are typically more cautious in their financial reporting (Herlambang and Darsono, 2015). Compared to smaller companies, large-scale companies tend to have more effective internal control systems, which assist in providing reliable financial information. Based on this explanation, the following hypothesis will be tested:

H3: Firm size has an effect on earnings management.

\subsection{Free Cash Flow and Earnings Management}

Free cash flow refers to the actual cash flow that is available to be distributed to investors after all operational expenses are paid (Agustia, 2013). A high free cash flow tends to indicate a higher risk of earnings management. Based on this explanation, the following hypothesis will be tested:

H4: Free cash flow has an effect on earnings management.

\subsection{Sales Growth and Earnings Management}

Mahapsari and Taman (2013) explain that sales growth is the rate of sales that changes from year to year. Sales growth may affect earnings management, as changes in the level of sales is used to measure a company's performance. Based on this explanation, the following hypothesis will be tested:

H5: Sales growth has an effect on earnings management.

\subsection{Managerial Ownership and Earnings Management}

Managerial ownership refers to the amount of a company's shares that are owned by managers, directors, and commissioners. A large managerial ownership can inhibit the risk of earnings management (Guna and Herawaty, 2010). Managers that are also shareholders tend to avoid earnings management, because of their interest, as a shareholder, in obtaining a return on their investment. Based on this explanation, the following hypothesis will be tested: 
H6: Managerial ownership has an effect on earnings management.

\subsection{Institutional Ownership and Earnings Management}

Institutional ownership refers to the amount of a company's shares that are owned by institutions, such as governments, financial institutions, legal institutions, foreign institutions, trust funds and others (Widigno, 2014). Institutional investors are considered more sophisticated and better at detecting earnings management, as they have greater access to information in a timely and relevant manner (Balsam et al., 2002). Thus, lower levels of institutional ownership may increase the ability of management to engage in earnings management (Pirzada et al. 2015). Based on this explanation, the following hypothesis will be tested:

H7: Institutional ownership has an effect on earnings management.

\subsection{Board Size and Earnings Management}

Aygun et al. (2014) states that the board of commissioners can be seen as an internal control mechanism and may have an impact on the likelihood that a company will engage in earnings management activities. The more members on the board of commissioners, the more scrutiny of management within the company, which will ultimately reduce their opportunity to engage in earnings management (Pirzada, 2016). Based on this explanation, the following hypothesis will be tested:

H8: Board size has an effect on earnings management.

\subsection{Audit Committee and Earnings Management}

The audit committee oversees the preparation of financial statements. The role of the audit committee is to ensure the quality of the financial statements as well as to minimize earnings management practices. If the audit committee is carrying out its role effectively, the opportunity for earnings management is reduced (Zeptian and Rohman, 2013). Based on this explanation, the following hypothesis will be tested:

H9: The audit committee has an effect on earnings management.

\subsection{Audit Quality and Earnings Management}

Audit quality is important in reducing earnings management. Susanto (2013) states that audit quality can reduce uncertainty in financial statements. One way to ensure a high quality of audits is to use the services of qualified and professional auditors (Zeptian and Rohman, 2013). Based on this explanation, the following hypothesis will be tested:

H10: Audit quality has an effect on earnings management.

\section{Research Methodology}

The population of this research is manufacturing companies listed on the Indonesian Stock Exchange. The research period examined is from 2013 to 2015. The sampling method used in this research is purposive sampling. The criteria used include manufacturing companies that reported financial statements using the Rupiah currency, during the period ending December 31, companies that have not reported a loss during the observation period, and companies that have institutional ownership. The data used in this research is secondary data obtained from the company's annual financial statements, as reported with the Indonesian 
Stock Exchange. A total of 64 companies are examined, with 192 data items returned. This research also uses multiple regression analysis to test the hypotheses. The following model is used in the research:

$$
\mathrm{EM}=\alpha+\beta 1 \mathrm{ROA}+\beta 2 \mathrm{LEV}+\beta 3 \mathrm{SIZE}+\beta 4 \mathrm{FCF}+\beta 5 \mathrm{SG}+\beta 6 \mathrm{MO}+\beta 7 \mathrm{IO}+\beta 8 \mathrm{BSIZE}+\beta 9 \mathrm{AC}+\beta 10 \mathrm{AQ}+\varepsilon(1)
$$

\subsection{Operational Definition}

Earnings management is measured using discretionary accruals from the Jones Model (Dechow et al, 1995). The formula for measuring corporate discretionary accruals is as follows:

DACCit $=$ TACCit $/$ Ait-1 $-[\alpha t(1 /$ Ait-1) $]+\alpha 1 i[(\triangle$ REVit $-\triangle$ RECit $) /$ Ait-1) $]+\alpha 2 i[$ PPEit $/$ Ait-1] (2)

TACCit $=$ Nlit - OCFit

(3)

Where:

DACCit $=$ Discretionary accruals

$\mathrm{NI}=$ Net Income

OCF $=$ Operating Cash Flows

$\triangle$ REVit $\quad=$ Change in Revenue

$\triangle$ RECit $\quad=$ Change in Receivable

PPE $=$ Gross Property, Plant and Equipment

Ait $-1=$ Total Asset $\mathrm{t}-1$

The operational definition of the independent variables is shown in Table 1 below:

Table 1. Variables Operational Definition

\begin{tabular}{|c|c|}
\hline Return on assets & Net income after tax / total assets (Guna and Herawaty, 2010) \\
\hline Financial leverage & Total liabilities / total asset (Aygun et. al, 2014) \\
\hline Firm size & Natural logarithm of total assets (Prasetya and Gayatri, 2016) \\
\hline Free cash flow & Free cash flow / total asset (Agustia, 2013) \\
\hline Sales Growth & Percentage of change in sales (Savitri, 2014) \\
\hline Managerial ownership & $\begin{array}{c}\text { 1 for companies with managerial ownership while 0 for firms with no } \\
\text { managerial ownership (Rahmawati, 2013) }\end{array}$ \\
\hline Institutional ownership & $\begin{array}{c}\text { Proportion of share ownership owned by non-management companies (Aygun } \\
\text { et. al, 2014) }\end{array}$ \\
\hline Board size & Number of board members within a company (Aygun et. al, 2014) \\
\hline Audit committee & Number of audit committee members of a company (Agustia, 2013) \\
\hline Audit quality & $\begin{array}{c}\text { 1 for companies audited by Big Four and number 0 for companies that are not } \\
\text { audited by Non-Big Four (Memis and Cetenak, 2012) }\end{array}$ \\
\hline
\end{tabular}

\section{Results and Discussion}

The result of the statistical test can be seen in hypotheses results shown in Table 2 below:

Table 2. Hypotheses Results

\begin{tabular}{|c|c|c|}
\hline Variable & B & Sig. \\
\hline (Constant) & 0,095 & 0,341 \\
\hline Return on Assets & 0,477 & 0,000 \\
\hline Financial Leverage & $-0,054$ & 0,049 \\
\hline Firm Size & $-0,004$ & 0,277 \\
\hline
\end{tabular}




\begin{tabular}{|c|r|r|}
\hline Free Cash Flow & $-0,473$ & 0,000 \\
\hline Sales Growth & $-0,123$ & 0,000 \\
\hline Managerial Ownership & $-0,004$ & 0,619 \\
\hline Institutional Ownership & $-0,026$ & 0,204 \\
\hline Board Size & 0,002 & 0,513 \\
\hline Audit Committee & 0,002 & 0,777 \\
\hline Audit Quality & $-0,007$ & 0,521 \\
\hline
\end{tabular}

Table 1 shows that return on assets, financial leverage, free cash flow, and sales growth all have an effect on earnings management. Meanwhile, other variables such as managerial ownership, institutional ownership, board size, audit committee, firm size, and audit quality have no significant effect on earnings management. Return on assets is often used to measure company performance. In order for a company's performance to be considered "good", a company's management usually undertakes some form of earnings management activity, to attract investors with what appears to be a high rate of return on assets. Further, by depicting a low level of leverage, the company is indicating that the returns on investment will be higher.

In addition, high levels of free cash flow illustrate that a company has sufficient capital to meet its financial and operational needs. Hence, the company's management may no longer be motivated to engage in earnings management, as there is no need to attract further investors. Companies that have high sales growth can attract investors quite easily. Hence, this also reduces the likelihood of earnings management practices. Similarly, if the sales growth of a company declines, then the opposite will be true.

On the other hand, firm size, corporate governance, and audit quality may not be able to reduce an earnings management practices. Earnings management may indeed be done with the intention of misleading stakeholders with respect to the entity's performance or affecting contractual outcomes. Further, earnings management is expected to decline with the introduction of an efficient legal system, because strong protection of stakeholder rights may inhibit the ability of insiders to gain personal benefits (Memis and Cetenak, 2012).

\section{Conclusion}

The main objective of this research was to explain the practices of earnings management according to audit quality, agency costs and managers' control mechanisms in the context of Indonesian firms.

The results suggest that the Big Four auditors do not reduce the discretionary accounting practices carried out by managers of Indonesian Small and Medium Firms. On the other hand, the Local Audit Large Offices seem rather cautious about these discretionary accounting practices. Hence, the hypothesis of the agency theory, tested in the Indonesian companies, shows that company characteristics (return on assets, financial leverage, free cash flow and sales growth) all have an effect on earnings management. Meanwhile, firm size, corporate governance, managerial ownership, institutional ownership, board size, audit committee, and audit quality have no significant effect on earnings management. These results highlights a contingency of the agency conflict in relation to Indonesian institutional data.

This research has several limitations. The object of the study is manufacturing companies listed on the Indonesian Stock Exchange and the variation of independent variables in this study can only be used to explain 55.9\% of the variation of the dependent variable. It is recommended that further research expand the study population and examine alternative independent variables that may have an effect on earnings management, such as operational cash flow. Although this paper has revealed the importance of the sociocultural factors and the governance factors in studying accounting problems, it does include some shortcomings which reduces the extent of its results. 
A comparative study between several countries or with environments close to Indonesia could bring about a better understanding of the influence of the socio-cultural factors on the practice of earnings management. It would be interesting to study, in a more recent period, the contribution of audit quality in the presence of audit committees and to analyze the eventual interactions that may exist between these two control mechanisms in relation to manager accounting strategies.

\section{References}

Ibrahim, A., \& Abdel-Azim, M. (2014). Investigating the impact of historical costing on real earnings management: an empirical study. International Business and Economics Research Journal, 13(2), 387400..https://doi.org/10.19030/iber.v13i2.8455

Agustia, D. (2013). The influence of good corporate governance, free cash flow, and leverage factors on earnings management. Journal of Accounting and Finance, 15 (1), 27-42.https://doi.org/10.9744/jak.15.1.27-42

Aygun, M., Ic, S., \& Sayim, M. (2014). The Effects of corporate ownership structure and board size on earnings management: Evidence from Turkey. International Journal of Business and Management, 9(12), 123. http://dx.doi.org/10.5539/ijbm.v9n12p123

Balsam, S., Bartov, E., \& Marquardt, C. (2002). Accruals management, investor sophistication, and equity valuation: Evidence from 10-Q filings. Journal of Accounting Research, 40(4), 987-1012. https://doi.org/10.1111/1475679X.00079

Dechow, P. M., Sloan, R. G., \& Sweeney, A. P. (1995). Detecting earnings management. Accounting review, $193-$ 225.https://www.jstor.org/stable/248303

Welvin, I., \& Herawaty, A. (2010). Influence of Good Corporate Governance Mechanism, Auditor Independence, Audit Quality and Other Factors to Profit Management. Journal of Business and Accounting, 12(1), 5368.http://jurnaltsm.id/index.php/JBA/article/view/162/137

Herlambang, S. and Darsono, D., 2015. Effect of Good Corporate Governance and Company Size on Earnings Management (Doctoral dissertation, Faculty of Economics and Business). https://ejournal3.undip.ac.id/index.php/accounting/article/view/9597

Jensen, M. C., \& Meckling, W. H. (1976). Theory of the firm: Managerial behavior, agency costs and ownership structure. Journal of financial economics, 3(4), 305-360.https://doi.org/10.1016/0304-405X (76)90026-X

Mahapsari, N.R. and Taman, A., 2013. Effect of Profitability, Structure of Assets, and Sales Growth on Stock Prices with Capital Structure as Intervening Variables in Manufacturing Companies on the Indonesia Stock Exchange. Nominal, Barometer of Accounting and Management Research, 2 (1). https://doi.org/10.21831/nominal.v2i1.1653

Pirzada, K., Mustapha, M. Z., \& Alfan, E. (2016). The Role of Nomination Committee in Selecting Female Directors: A Case of Malaysia. Pirzada K., MZ, M. Alfan, E. (2016). The Role of Nomination Committee in Selecting Female Directors: A Case of Malaysia. Pertanika Journal of Social Sciences \& Humanities, 24.https://papers.ssrn.com/sol3/papers.cfm?abstract_id=2897276

Pirzada, K., Mustapha, M. Z. B., \& Wickramasinghe, D. (2015). Firm Performance, Institutional Ownership and Capital Structure: A Case of Malaysia. Procedia-Social and Behavioral Sciences, 211, 170-176.Procedia-Social and Behavioral Sciences, 211, pp.170-176. https://doi: 10.1016/j.sbspro.2015.11.025 